\title{
SIMPANAN KARBON PADANG LAMUN DI KAWASAN PANTAI SANUR, KOTA DENPASAR
}

\author{
Yoga Ibnu Graha ${ }^{1 *)}$, I Wayan Arthana ${ }^{2)}$, I Wayan Gede Astawa Karang ${ }^{2)}$ \\ 1) Balai Pengelolaan Sumber Daya Pesisir Dan Laut Denpasar \\ 2) Fakultas Kelautan dan Perikanan, Universitas Udayana \\ *)Email :yogamelvoin@gmail.com
}

\begin{abstract}
Seagrass is one of the marine resources that considerably potential as a $\mathrm{CO}_{2}$ absorbent and functioned as carbon sinks in the oceans known as blue carbon. The result of carbon sequestration from the process of photosynthesis is stored as carbon stocks on seagrass tissue, or streamed to multiple compartments, such as sediment, herbivores and other ecosystems. This study aims to assess the potential for carbon stock storage in biomass on a tissue of seagrass in Sanur Beach coastal area. The observations of seagrass are included the seagrass type, seagrass stands, and measurement of environmental parameters. Then the sampling was conducted to obtain the value of seagrass biomass. The carbon stocks obtained through the conversion of biomass by using carbon concentration analysis of seagrass tissue and then carried a spatial distribution of carbon stocks. Types of seagrass found in Sanur Beach coastal area consist of eight species that are Enhalus acroides, Thalassia hemprichii, Halophila ovalis, Syringodium isoetifolium, Cymodocea serrulata, Cymodocea rotundata, Halodule uninervis and Halodule pinifolia. The result of the carbon stock seagrass in the bottom substrate is $60 \%$ greater than the carbon stock in the top substrate which is $40 \%$. Seagrass covering 322 ha of Sanur Beach coastal area with a total potential carbon storage of 66.60 tons or 0.21 tons / ha. Seagrass key role as a carbon storage is on the bottom substrate tissue, and Enhalus acroides is a seagrass species that contributes the most to the carbon storage.
\end{abstract}

Keywords: carbon storage, seagrass, Sanur Beach.

\section{PENDAHULUAN}

Peran vegetasi sebagai penyerap karbon sebelumnya hanya fokus terhadap vegetasi darat seperti hutan dan perkebunan atau disebut dengan green carbon (Ulumuddin, et al. 2005; Aminudin, 2008). Bukti ilmiah hingga kini juga sudah menguak bahwa ada ekosistem laut tertentu yang berperan sebagai rosot karbon (carbon sinks). Potensi ekosistem laut yang berperan dalam menyerap karbon dari atmosfer lewat fotosintesis, yaitu berupa plankton yang mikroskopis maupun yang berupa tumbuhan yang hanya hidup di pantai seperti di hutan mangrove, padang lamun, ataupun rawa payau (salt marsh). Lamun merupakan tumbuhan berbunga (Angiospermae) yang memiliki kemampuan beradaptasi secara penuh di perairan yang memiliki fluktuasi salinitas tinggi, hidup terbenam di dalam air dan memiliki rhizoma, daun, dan akar sejati. Komunitas lamun berada di antara batas terendah daerah pasang surut sampai kedalaman tertentu dimana cahaya matahari masih dapat mencapai dasar laut (Sitania, 1998). Berbagai jenis ikan menjadikan daerah padang lamun sebagai daerah mencari makan (feeding ground), pengasuhan larva (nursery ground), tempat memijah (spawning ground), sebagai stabilitas dan penahanan sedimen, mengurangi dan memperlambat pergerakan gelombang, sebagai tempat terjadinya siklus nutrien (Philips dan Menez 1988) dan fungsinya sebagai penyerap karbon di lautan (carbon sink) atau dikenal dengan istilah blue carbon (Kawaroe, 2009).

Lamun yang hidup di kawasan Pantai Sanur tumbuh di hamparan pantai sepanjang sekitar $8 \mathrm{~km}$ yang terbentang dari Pantai Sanur sampai Mertasari. Substrat dasar tempat lamun itu tumbuh terdiri atas pasir, pecahan karang, karang mati, batuan massif, karang dan algae (Bali Beach Conservation Project, 1998; Arthana, 2004). Padang lamun ini selain sebagai penyeimbang ekosistem disekitarnya, diharapkan juga dapat memberikan peranan lain secara optimal yaitu sebagai salah satu penyerap $\mathrm{CO}_{2}$ dari atmosfer dalam kaitannya mengurangi emisi karbon dalam proses pemanasan global.

Kontribusi vegetasi lamun terhadap penyerapan karbon dimulai dari proses fotosintesis yang kemudian disimpan sebagai biomassa. Biomassa lamun adalah satuan berat (berat kering atau berat abu) lamun bagian tumbuhan yang berada di atas substrat (daun, seludang, buah dan bunga) dan atau bagian di bawah substrat (akar dan rimpang) yang sering dinyatakan dalam satuan gram berat kering per $\mathrm{m}^{2}\left(\mathrm{gbk} / \mathrm{m}^{2}\right)$. Karbon dalam biomassa ini akan tersimpan selama lamun masih hidup.

Sehubungan dengan hal tersebut, dilakukan 
penelitian dengan judul Simpanan Karbon Padang Lamun Di Kawasan Pantai Sanur, Kota Denpasar dengan tujuan untuk mengestimasi potensi penyimpanan karbon dalam biomassa (stok karbon) pada jaringan lamun di bagian atas substrat (daun) dan bagian bawah substrat (akar dan rhizoma).

\section{METODOLOGI}

Penelitian ini dilakukan pada bulan Juni tahun 2014 sampai dengan bulan Februari tahun 2015 di Perairan Pantai Sanur, Kota Denpasar, Provinsi Bali. Lokasi penelitian terdiri dari 8 stasiun, dengan masing-masing stasiun terdiri dari 3 transek kuadrat (a,b dan c) sehingga total titik transek yaitu 24 titik pengamatan. Sebaran ekosistem padang lamun yang terdapat di Pantai Sanur yakni seluas 322 ha Dinas Kelautan Peternakan, Perikanan dan Kelautan Kota Denpasar, 2014). Sebaran lamun di Pantai Sanur dikelompokkan dalam tipe yang berdampingan langsung dengan habitat terumbu karang dan mempunyai keterkaitan (linked) dengan ekosistem mangrove di sekitarnya. Peta sebaran dan titik pengamatan padang lamun dapat dilihat pada Gambar 1.

\subsection{Kondisi Umum Lamun}

Pengamatan kondisi umum lamun dilakukan dengan pengumpulan data yaitu mengkaji kerapatan lamun berdasarkan penentuan lokasi pengambilan sampel. Kerapatan adalah jumlah individu (tegakan) suatu jenis lamun per-satuan luas (satuan umum yang dipakai adalah per 1 meter persegi). Kerapatan lamun diperoleh dengan menghitung tegakan (lunas) lamun dan diamati dengan menggunakan transek kuadrat berukuran $100 \mathrm{~cm}$ x $100 \mathrm{~cm}$ Untuk memudahkan pengamatan, pada transek dibuat kisikisi $20 \mathrm{~cm} \mathrm{x} 20 \mathrm{~cm}$. Titik-titik pengamatan tersebar di semua perairan Pantai Sanur yang mempunyai padang lamun sehingga bisa mewakili kondisi umum lamun di Pantai Sanur.

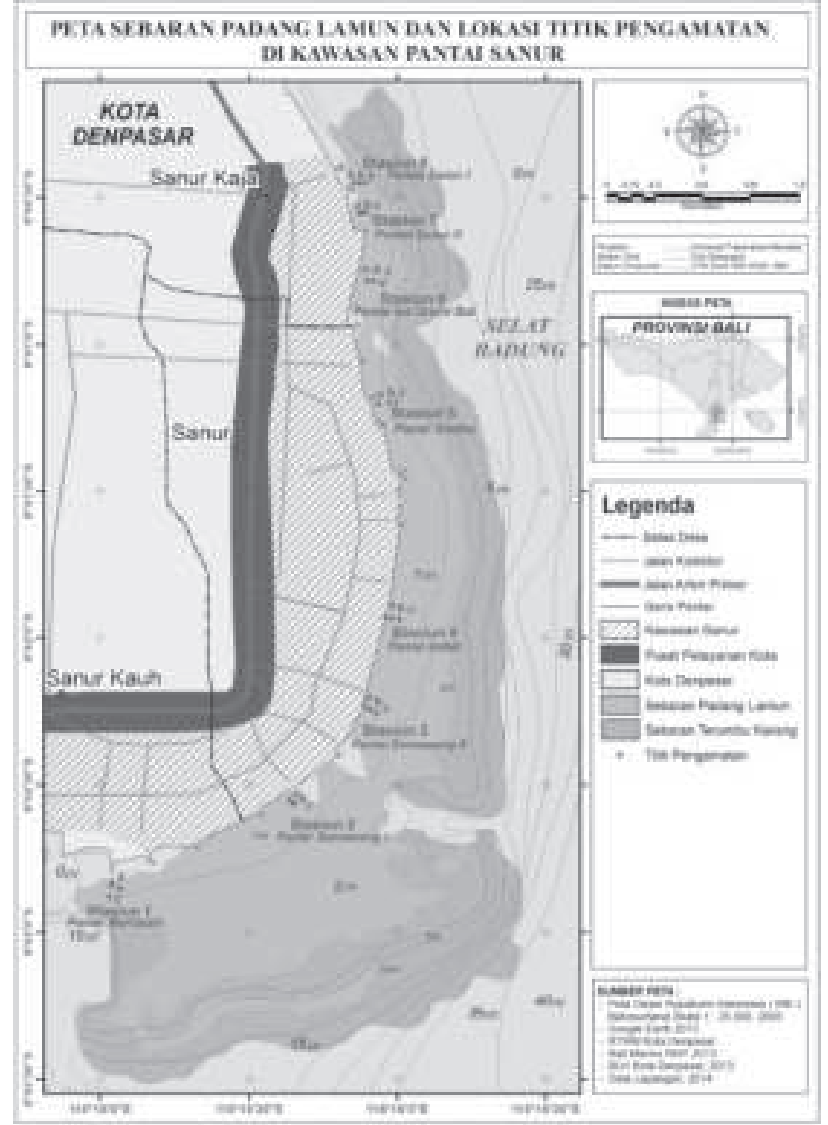

Gambar 1. Peta Sebaran dan Titik Pengamatan Lamun di Kawasan Pantai Sanur

\subsection{Biomassa dan Konsentrasi Karbon Jaringan Lamun}

Sampling biomassa dilakukan dengan menggunakan transek yang berukuran $20 \mathrm{~cm}$ x 20 $\mathrm{cm}$. Pencuplikan sampel lamun dilakukan dengan 3 kali pengambilan sampel lamun untuk biomassa di setiap titik pengamatan (transek kuadrat) yang nantinya akan dirata-rata dan dipisahkan daun, rhizoma dan akar untuk diketahui berat basah dan berat keringnya.

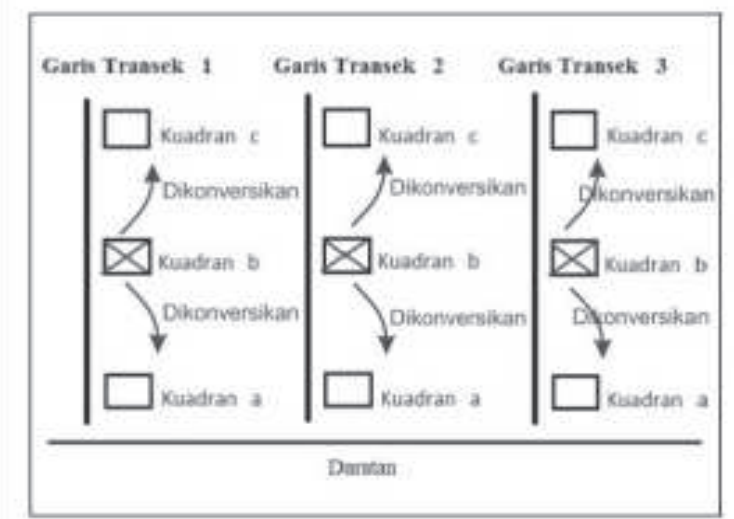

\section{= Dilakukan pengambilan sampel biomassa dan penghitungan nilai karbon}

\section{= Dilakukan pengambilan sampel biomassa}

\section{Keterangan:}

1. Penghitungan kandungan karbon dilakukan pada kuadran $b$ di setiap titik pengamatan.

2. Nilai kandungan karbon yang didapatkan kemudian dikonversikan ke titik kuadran a dan c berdasarkan perbandingan nilai karbon kuadran $b$ dengan berat basah dan biomassa di kuadran a dan $\mathrm{c}$ di setiap garis transek 
Penghitungan nilai kandungan karbon lamun perjaringan (daun, rhizoma dan akar) dianalisis dengan menggunakan metode Walkley dan Black (Sulaeman et al. 2005) dan metode pengabuan (Helrick, 1990) yang dilakukan di Laborarorium Tanah Fakultas Peternakan Universitas Udayana. Ilustrasi penghitungan nilai kandungan karbon dan konversi pada titik pengamatan lamun dapat dilihat pada Gambar 2.

\subsection{Total Stok Karbon Lamun}

Hasil analisis kandungan karbon lamun perjaringan (akar, rhizoma dan akar) dibagi menjadi stok karbon lamun bagian atas subtrat (daun) dan bagian bawah substrat (akar dan rhizoma). Kemudian di petakan sebaran stok karbon lamun dengan membagi lima kelas untuk mempermudah analisis dan setiap kelas stok karbon dihitung luasnya kemudian dijumlahkan dengan kelas-kelas lainnya sehingga didapatkan peta sebaran total stok karbon.

Pemetaan sebaran stok karbon lamun tersebut dengan menggunakan interpolasi yakni metode invers distance. Inti dari model ini adalah menganalisis titik pengamatan dalam suatu ruang ketetanggaan yang menggambarkan kemiripan diantara titik-titik tersebut. Proses interpolasi perlu dilaksanakan untuk mengestimasi dan memetakan potensi penyerapan karbon lamun dengan mudah dan cepat yakni mendapatkan nilai diantara titik sampel yaitu nilai karbon yang terkandung dalam lamun yang diamati. Untuk total stok karbon lamun di kawasan Pantai Sanur dianalisis dengan menggunakan konversi data biomassa menjadi kandungan karbon yang didapatkan pada awal penelitian. Data hasil konversi ke karbon keseluruhan kemudian diratarata dengan satuan gbk $/ \mathrm{m}^{2}$. Setelah mendapatkan nilai rata-rata karbon per meter persegi kemudian dikalikan dengan luas lamun yang ada di kawasan Pantai Sanur.

\section{HASIL}

\subsection{Kondisi Umum Lamun}

Berdasarkan hasil pengamatan yang diperoleh dari 24 titik pengamatan didapatkan delapan jenis spesies lamun di wilayah perairan Pantai Sanur yaitu E. acoroides, T. hemprichii, H. ovalis (famili Hydrocharitaceae), C. rotundata, C. serulata, $H$. uninervis, $H$. pinifolia dan S. isoetifolium (famili Potamogetonaceae). Dari delapan jenis lamun yang ditemukan dari 8 stasiun (24 titik pengamatan), jenis lamun E. acroides yang paling sering ditemukan pada enam stasiun yakni pada stasiun 1 (pantai Mertasari), stasiun 2 (pantai Semawang I), stasiun 3 (pantai Semawang II), stasiun 4 (pantai Indah), stasiun 5 (pantai Sindhu) dan stasiun 7 (pantai Sanur II). Kerapatan jenis lamun di lokasi penelitian secara keseluruhan disajikan pada Tabel 1.

Tabel 1. Kerapatan Lamun di Lokasi Penelitian

\begin{tabular}{|c|c|c|c|c|c|c|c|c|c|c|}
\hline \multirow{2}{*}{ Stasiun } & \multirow{2}{*}{ Transek Kuadrat } & \multicolumn{7}{|c|}{ Jenis Lamun (ind $/ \mathrm{m}^{2}$ ) } & \multirow[b]{2}{*}{ Si } & \multirow{2}{*}{ Total (ind $/ \mathrm{m}^{2}$ ) } \\
\hline & & Ea & $T h$ & $\mathrm{Cr}$ & Cs & $H u$ & $H p$ & Ho & & \\
\hline \multirow[t]{3}{*}{1} & $A$ & - & - & - & - & 238 & - & - & - & 238 \\
\hline & B & 21 & - & - & - & 158 & - & - & - & 179 \\
\hline & $\mathrm{C}$ & - & - & - & - & 196 & - & - & - & 196 \\
\hline \multirow[t]{3}{*}{2} & A & 78 & - & - & - & - & - & - & - & 78 \\
\hline & B & - & 236 & - & - & - & - & - & - & 236 \\
\hline & $\mathrm{C}$ & 128 & - & - & - & - & - & - & - & 128 \\
\hline \multirow[t]{3}{*}{3} & A & 62 & - & - & - & - & - & - & - & 62 \\
\hline & B & 85 & - & - & - & - & - & - & - & 85 \\
\hline & $C$ & 87 & - & - & - & - & - & - & - & 87 \\
\hline \multirow[t]{3}{*}{4} & A & 65 & 10 & - & 15 & 30 & - & - & - & 120 \\
\hline & $\mathrm{B}$ & 96 & - & - & 12 & - & - & - & - & 108 \\
\hline & $\mathrm{C}$ & $\pi$ & - & - & 8 & - & - & - & - & 85 \\
\hline \multirow[t]{3}{*}{5} & $A$ & - & - & - & - & 306 & - & 309 & - & 615 \\
\hline & B & 27 & 169 & - & - & 5 & - & - & 15 & 216 \\
\hline & C & - & - & - & - & 232 & - & - & 456 & 688 \\
\hline \multirow[t]{3}{*}{6} & $A$ & - & - & 158 & - & - & 272 & 535 & - & 965 \\
\hline & $B$ & - & - & 6 & - & 463 & 11 & 29 & - & 509 \\
\hline & C & - & - & 305 & - & 299 & 294 & - & - & 898 \\
\hline \multirow[t]{3}{*}{7} & $A$ & 101 & - & 50 & - & - & 30 & - & - & 181 \\
\hline & $B$ & - & - & 197 & - & - & 356 & - & - & 553 \\
\hline & C & - & - & 16 & - & - & - & 438 & - & 454 \\
\hline \multirow[t]{3}{*}{8} & $A$ & - & - & - & - & 109 & - & 10 & 445 & 564 \\
\hline & B & - & - & 71 & - & 33 & - & & 545 & 649 \\
\hline & C & - & - & - & - & 120 & - & 150 & 199 & 469 \\
\hline
\end{tabular}

Sumber: Hasil pengamatan Lapang

Keterangan:

$\mathrm{Ea}=\mathrm{E}$. acoroides; $\mathrm{Th}=\mathrm{T}$. hemprichii; $\mathrm{Cr}=\mathrm{C}$. rotundata; $\mathrm{Cs}=\mathrm{C}$. serrulata; $\mathrm{Hu}=\mathrm{H}$. uninervis; $\mathrm{Hp}=\mathrm{H}$. pinifolia; $\mathrm{Ho}=\mathrm{H}$. ovalis dan $\mathrm{Si}=\mathrm{S}$. Isoetifolium 
Perbedaan jenis lamun dan kerapatan pada masing-masing titik pengamatan ini diduga berkaitan dengan kemampuan adaptasi jenis lamun tersebut terhadap kondisi lingkungan yang berbeda. Berdasarkan hasil pengamatan didapatkan nilai kerapatan jenis lamun $S$. isoetifolium mempunyai nilai paling tinggi di semua stasiun pengamatan yaitu berkisar pada $15-545$ individu/ $\mathrm{m}^{2}$. Jenis lamun $H$. ovalis mempunyai nilai kerapatan sebesar $10-535$ individu/ $\mathrm{m}^{2}$. Jenis lamun $H$. uninervis sebesar 5-463 individu/ $\mathrm{m}^{2}$, jenis lamun $H$. pinifolia sebesar 11 - 356 individu/ $\mathrm{m}^{2}$, jenis lamun $C$. rotundata sebesar $6-305$ individu/ $\mathrm{m}^{2}$, jenis lamun T. hemprichii sebesar $10-236 \mathrm{individu} / \mathrm{m}^{2}$, jenis lamun $E$. acroides sebesar $21-128$ individu/ $\mathrm{m}^{2}$. Sedangkan jenis lamun C. serrulata hanya ditemukan pada stasiun 4 dengan nilai kerapatan sebesar $8-15$ individu/ $\mathrm{m}^{2}$.

Nilai total frekuensi kemunculan jenis lamun di seluruh titik pengamatan didapatkan jenis $H$. uninervis yang memiliki nilai frekuensi tertinggi sebesar $50 \%$ dari keseluruhan transek diikuti oleh jenis $E$. acroides sebesar $46 \%$, C. rotundata sebesar $29 \%, H$. ovalis sebesar $25 \%, H$. pinifolia sebesar $21 \%$, S. isoetifolium sebesar $21 \%$ dan nilai frekuensi kemunculan yang terkecil yakni jenis $C$. serrulata sebesar $12,5 \%$. Kehadiran lamun di suatu lokasi sangat berkaitan dengan ruang dan tipe substrat dasar. Kebanyakan spesies lamun sangat cocok dengan tipe substrat berpasir sampai berlumpur (Duarte et al, 2012).

\subsection{Biomassa Lamun}

Nilai total biomassa lamun $\left(\mathrm{m}^{2}\right)$ yang diperoleh berkisar 26,33 - 235 gram berat kering (gbk)/ $\mathrm{m}^{2}$ yang terdiri dari total biomassa diatas substrat sebesar $16,08-97,17 \mathrm{gbk} / \mathrm{m}^{2}$ dan total biomassa di bawah substrat sebesar $9,92-145,67 \mathrm{gbk} / \mathrm{m}^{2}$.

Nilai total biomassa yang tertinggi di temukan pada stasiun 4 di kuadran C sebesar $235 \mathrm{gbk} / \mathrm{m}^{2}$ didominasi oleh jenis $E$. acroides dan diikuti oleh stasiun 2 di kuadran C sebesar 205,8 gbk/ $\mathrm{m}^{2}$ yang hanya didominasi oleh jenis $E$. acroides. Sedangkan nilai total biomassa terkecil ditemukan pada stasiun 6 di kudran A sebesar 26,33 gbk/ $\mathrm{m}^{2}$ yang didominasi oleh jenis $H$. ovalis dan $H$. pinifolia diikuti oleh stasiun 1 Kuadran B sebesar 42,92 gbk/ $\mathrm{m}^{2}$ yang didominasi oleh jenis $H$. uninervis. Sebaran biomassa lamun bagian atas dan bagian bawah substrat pada masing-masing transek dapat disajikan pada Gambar 3.

Persentase keseluruhan biomassa di atas substrat pada semua titik pengamatan sebesar $39,84 \%$ sedangkan biomassa di bawah substrat berkisar sebesar $60,16 \%$. Secara umum pada penelitian ini nilai biomassa bawah substrat lebih tinggi dibandingkan nilai biomassa atas substrat.

\subsection{Karbon Lamun}

Tumbuhan lamun memiliki kandungan karbon yang menggambarkan seberapa besar lamun tersebut dapat mengikat $\mathrm{CO}_{2}$ dari udara. Kandungan karbon dapat diartikan yaitu banyaknya karbon yang mampu diserap oleh tumbuhan lamun dalam bentuk biomassa. Hasil analisis menghasilkan nilai kandungan karbon perjaringan dan telah dikonversi menjadi bagian atas substrat dan bawah substrat yang disajikan pada Tabel 2.

Setelah diketahui nilai hasil konversi kandungan karbon dengan metode Walkley and Black dan metode pengabuan ke dalam satu meter persegi pada masingmasing jaringan lamun pada setiap titik pengamatan, kemudian dilakukan rata-rata kandungan karbon lamun dari dua metode tersebut yang terdiri dari kandungan karbon lamun bagian atas substrat dan kandungan karbon lamun bagian bawah substrat. Hasil rata-rata inilah yang digunakan sebagai nilai stok kandungan karbon lamun.

Nilai kandungan karbon di bawah substrat berkisar antara $1,62-29,54 \mathrm{gC} / \mathrm{m}^{2}$. Nilai tertinggi ditemukan di stasiun $2 \mathrm{C}$ (kuadran c) yakni di Pantai Semawang I sebesar $29,54 \mathrm{gC} / \mathrm{m}^{2}$ yang didominasi

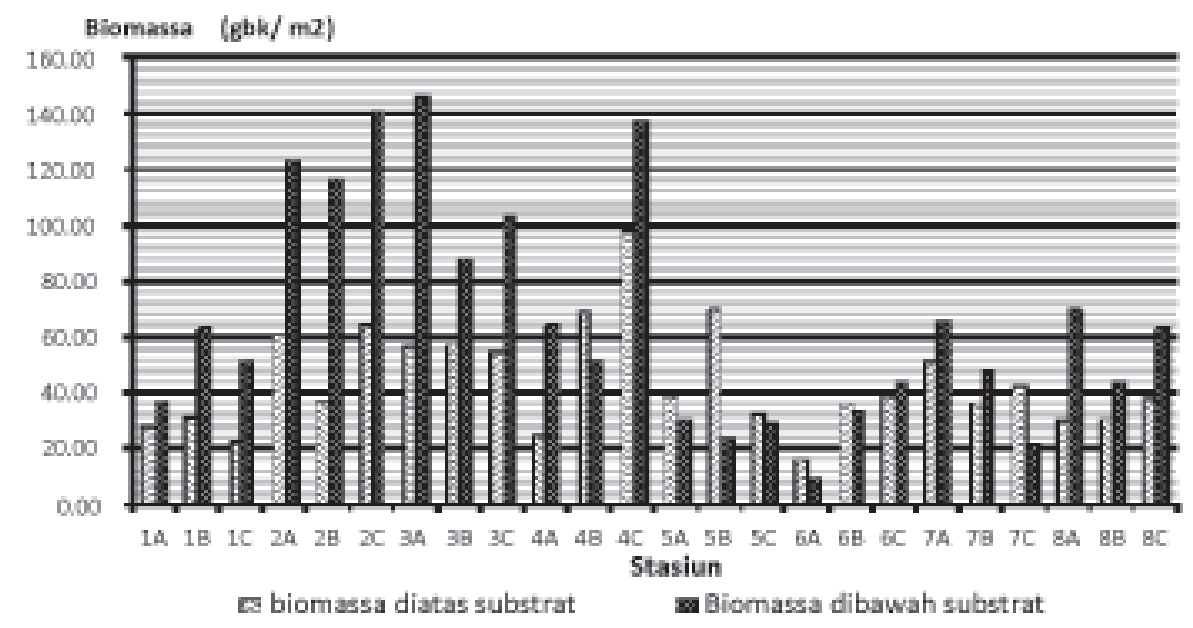

Gambar 3. Grafik Sebaran Biomassa Lamun 
Tabel 2. Rerata Nilai Kandungan Karbon Lamun

\begin{tabular}{|c|c|c|c|c|c|c|c|}
\hline \multirow[t]{2}{*}{ Stasiun } & \multicolumn{2}{|c|}{$\begin{array}{c}\text { Metode Walkley \&Black } \\
\left(\mathrm{gC} / \mathrm{m}^{2}\right)\end{array}$} & \multicolumn{2}{|c|}{$\begin{array}{l}\text { Metode Pengabuan } \\
\qquad\left(\mathrm{gC} / \mathrm{m}^{2}\right)\end{array}$} & \multicolumn{3}{|c|}{$\begin{array}{c}\text { Rerata dari metodeWalkley \& Black } \\
\text { Dan Pengabuan }\left(\mathrm{gC} / \mathrm{m}^{2}\right)\end{array}$} \\
\hline & $\begin{array}{l}\text { Bawah } \\
\text { Substrat }\end{array}$ & $\begin{array}{c}\text { Atas } \\
\text { Substrat }\end{array}$ & $\begin{array}{l}\text { Bawah } \\
\text { Substrat }\end{array}$ & $\begin{array}{c}\text { Atas } \\
\text { Substrat }\end{array}$ & $\begin{array}{l}\text { Bawah } \\
\text { Substrat }\end{array}$ & $\begin{array}{c}\text { Atas } \\
\text { Substrat }\end{array}$ & $\begin{array}{l}\text { Rerata } \\
\text { Total }\end{array}$ \\
\hline $1 \mathrm{~A}$ & 6.5000 & 4.6144 & 5.6907 & 4.5297 & 6.0953 & 4.6144 & 10.7097 \\
\hline $1 \mathrm{~B}$ & 11.0935 & 5.1912 & 9.7744 & 5.0967 & 10.4339 & 5.1440 & 15.5779 \\
\hline $1 \mathrm{C}$ & 9.3100 & 3.7080 & 8.3382 & 3.6399 & 8.8241 & 3.6740 & 12.4980 \\
\hline $2 \mathrm{~A}$ & 27.2704 & 12.4812 & 23.0932 & 11.5210 & 25.1818 & 12.0011 & 37.1828 \\
\hline $2 B$ & 25.2649 & 7.5815 & 20.0099 & 6.9983 & 22.6374 & 7.2899 & 29.9273 \\
\hline $2 \mathrm{C}$ & 31.4480 & 13.2032 & 27.6370 & 12.1875 & 29.5425 & 12.6953 & 42.2378 \\
\hline $3 \mathrm{~A}$ & 26.9105 & 11.7633 & 19.6085 & 9.3074 & 23.2595 & 10.5354 & 33.7949 \\
\hline $3 B$ & 16.9700 & 11.9195 & 13.2769 & 9.4310 & 15.1235 & 10.6752 & 25.7987 \\
\hline $3 C$ & 20.4235 & 11.3469 & 16.5030 & 8.9780 & 18.4632 & 10.1624 & 28.6257 \\
\hline $4 \mathrm{~A}$ & 15.2002 & 5.1864 & 13.0725 & 4.2108 & 14.1363 & 4.6986 & 18.8349 \\
\hline $4 \mathrm{~B}$ & 11.2349 & 14.2240 & 10.0148 & 11.5484 & 10.6248 & 12.8862 & 23.5110 \\
\hline $4 \mathrm{C}$ & 30.5152 & 19.9752 & 27.0653 & 16.2177 & 28.7903 & 18.0964 & 46.8867 \\
\hline $5 \mathrm{~A}$ & 6.1946 & 7.9911 & 5.4455 & 7.8950 & 5.8200 & 7.9431 & 13.7631 \\
\hline $5 \mathrm{~B}$ & 5.2430 & 14.2918 & 4.8988 & 14.1199 & 5.0709 & 14.2058 & 19.2767 \\
\hline $5 \mathrm{C}$ & 5.7279 & 6.5568 & 4.9429 & 6.4780 & 5.3354 & 6.5174 & 11.8528 \\
\hline $6 \mathrm{~A}$ & 1.8189 & 3.3924 & 1.4170 & 3.0196 & 1.6179 & 3.2060 & 4.8239 \\
\hline $6 \mathrm{~B}$ & 5.9701 & 6.0300 & 4.6158 & 6.5882 & 5.2930 & 6.3091 & 11.6020 \\
\hline $6 \mathrm{C}$ & 7.6759 & 7.9670 & 5.8934 & 7.0914 & 6.7847 & 7.5292 & 14.3139 \\
\hline $7 \mathrm{~A}$ & 12.1566 & 8.5027 & 11.8434 & 8.6809 & 12.0000 & 8.5918 & 20.5918 \\
\hline $7 \mathrm{~B}$ & 8.2693 & 5.9023 & 7.2372 & 6.0261 & 7.7532 & 5.9642 & 13.7174 \\
\hline $7 \mathrm{C}$ & 3.8634 & 7.0580 & 3.6790 & 7.2060 & 3.7712 & 7.1320 & 10.9032 \\
\hline $8 \mathrm{~A}$ & 12.2304 & 6.2678 & 10.4525 & 5.7302 & 11.3414 & 5.9990 & 17.3404 \\
\hline $8 B$ & 8.5493 & 6.3705 & 7.6366 & 5.8242 & 8.0930 & 6.0973 & 14.1903 \\
\hline $8 \mathrm{C}$ & 11.7456 & 7.7576 & 10.2884 & 7.0924 & 11.0170 & 7.4250 & 18.4420 \\
\hline
\end{tabular}

oleh jenis E.acroides. Nilai kandungan karbon di bawah substrat terkecil ditemukan di stasiun $6 \mathrm{~A}$ (Pantai Ina Grand Bali) sebesar 1,61 gC/m² yang didominasi oleh jenis $H$. ovalis dan $H$. pinifolia.

Nilai kandungan karbon di atas substrat berkisar antara $3,21-18,10 \mathrm{gC} / \mathrm{m}^{2}$. Nilai tertinggi ditemukan di stasiun 4C (Pantai Indah) sebesar 18,10 $\mathrm{gC} / \mathrm{m}$ yang didominasi oleh jenis $E$. acroides. Nilai kandungan karbon di atas substrat terkecil ditemukan di stasiun 6A (Pantai Ina Grand Bali) sebesar $3,21 \mathrm{gC} / \mathrm{m}^{2}$ yang didominasi oleh $H$. ovalis dan $H$. pinifolia. Secara umum kandungan karbon di bawah substrat lebih tinggi dibandingkan dengan kandungan karbon di atas substrat.

\subsection{Total Penyimpanan Stok Karbon}

Rata-rata total stok karbon lamun bagian atas dan bawah substrat dari semua titik pengamatan yakni sebesar $20,05 \mathrm{gC} / \mathrm{m}^{2}$ dengan kisaran antara $4.82-46.89 \mathrm{gC} / \mathrm{m}^{2}$. Stok karbon tertinggi ditemukan pada stasiun $4 \mathrm{C}$ (Pantai Indah) sebesar $46.89 \mathrm{gC} / \mathrm{m}^{2}$ yang didominasi oleh jenis lamun $E$. acroides dan terkecil ditemukan di stasiun 6A (Pantai Inna Grand Bali) sebesar $4.82 \mathrm{gC} / \mathrm{m}^{2}$ yang didominasi oleh jenis lamun $H$. ovalis. Grafik total stok karbon lamun dapat dilihat pada Gambar 4 dan Peta distribusi total stok karbon lamun dapat dilihat pada Gambar 5.

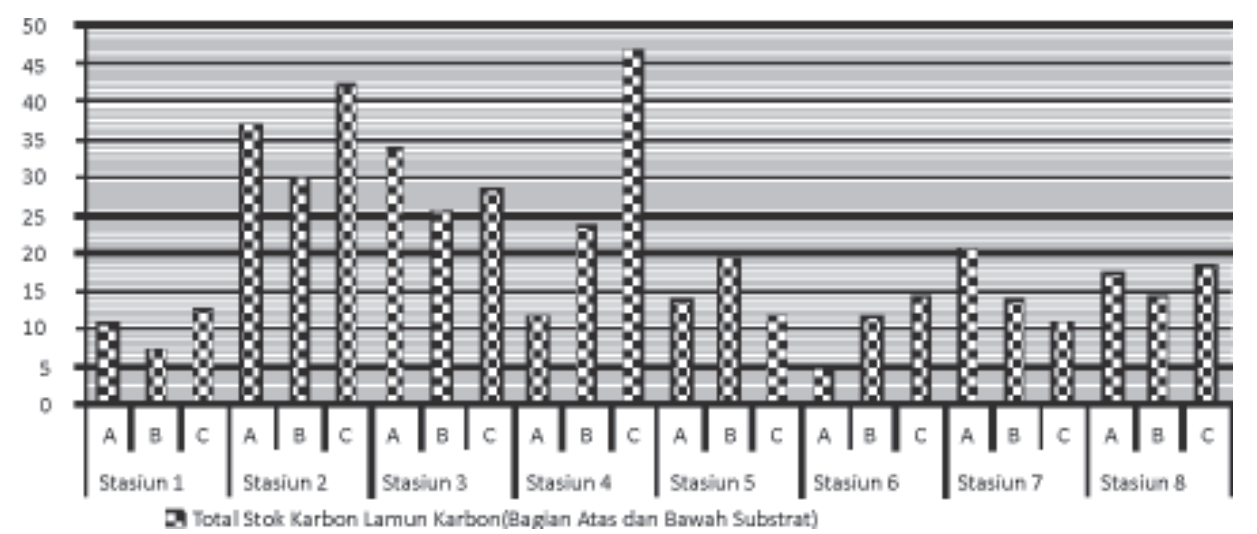

Gambar 4. Total Stok Karbon Lamun pada masing-masing Transek 


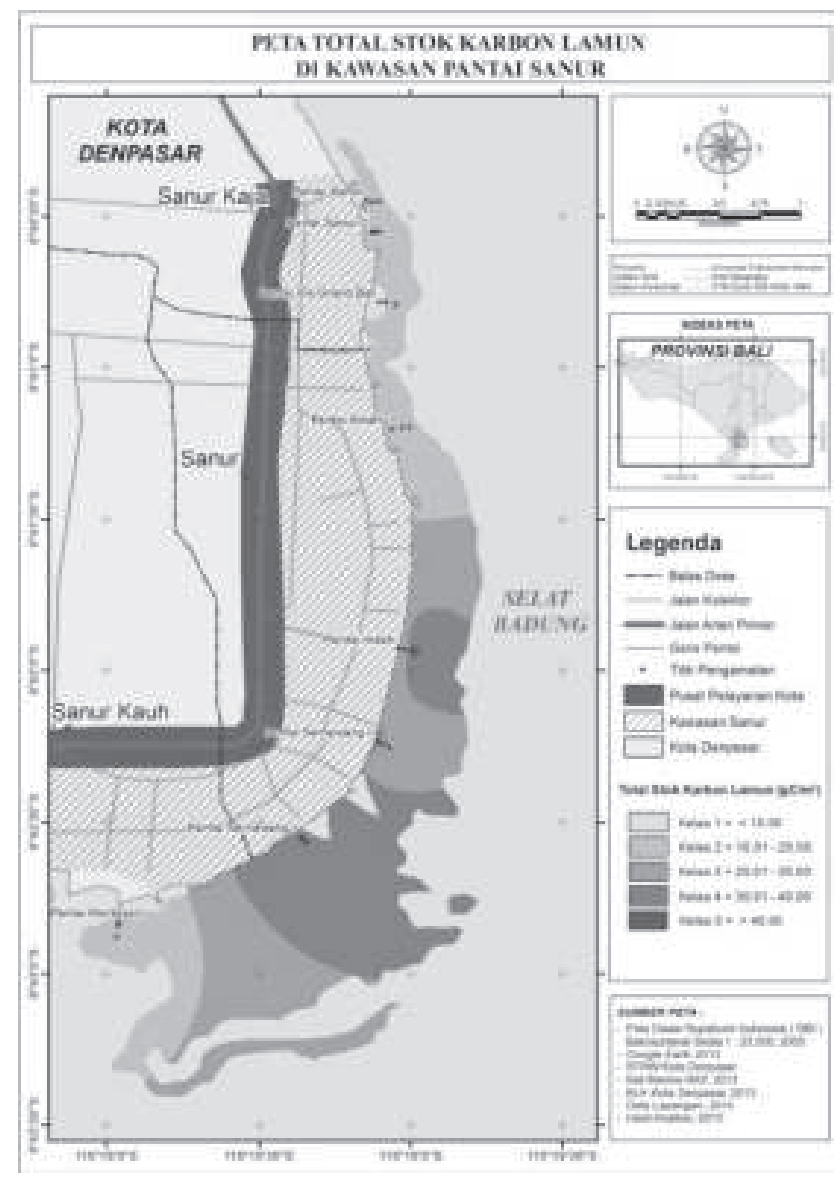

Gambar 5. Peta Total Sebaran Stok Karbon Lamun

Berdasarkan peta diatas dan sesuai dengan luas total padang lamun sebesar $322 \mathrm{Ha}$ maka pembagian masing-masing luas kelas stok karbon yakni kelas total stok karbon lamun tertinggi ditemukan pada kelas $3\left(20,01-30,00 \mathrm{gC} / \mathrm{m}^{2}\right)$ sebesar 119,14 Ha atau $37 \%$ dari luas keseluruhan padang lamun. Kemudian diikuti oleh kelas $2\left(10,01-20,00 \mathrm{gC} / \mathrm{m}^{2}\right)$ sebesar 89,58 atau $27,82 \%$ dan seterusnya oleh kelas $4(30,01$ - 40,00 gC/m²) sebesar 111,04 Ha atau 34,48\%, kelas $1\left(<5,00 \mathrm{gC} / \mathrm{m}^{2}\right)$ sebesar $1,9 \mathrm{Ha}$ atau $0,59 \%$ dan luas terkecil yakni pada kelas $5\left(>40,00 \mathrm{gC} / \mathrm{m}^{2}\right)$ sebesar $0,34 \mathrm{Ha}$ atau $0,11 \%$ dari luas keseluruhan padang lamun di kawasan Pantai Sanur.

Hasil perhitungan total stok karbon lamun di bawah substrat sebesar 39,85 ton karbon atau $60 \%$ lebih besar dibandingkan dengan total stok karbon lamun di atas substrat yang hanya $40 \%$ (26,75 ton karbon). Sedangkan untuk total stok karbon lamun diperoleh total sebesar $66.600 .749 \mathrm{gC}$ atau sebesar 66,60 ton karbon. Sehingga padang lamun yang tumbuh di kawasan Pantai Sanur mempunyai potensi penyimpanan karbon sebesar 66,60 ton atau setara dengan 0,21 ton/ha karbon yang terdiri dari bagian lamun di atas substrat dan di bawah substrat. Sebaran total stok karbon lamun di perairan sebelah selatan (stasiun 1,2,3 dan 4) lebih besar karena rataan/ lebar lamun yang tumbuh lebih luas sekitar $0-820 \mathrm{~m}$ dibandingkan dibagian utara (stasiun 5,6,7 dan 8) sekitar 0-180 $\mathrm{m}$ dan juga karena di perairan selatan didominasi oleh jenis lamun $E$. acroides yang secara morfologi lebih besar dibandingkan jenis lainnya.

\section{PEMBAHASAN}

\subsection{Kondisi Komunitas Lamun di Kawasan Pantai Sanur}

Secara keseluruhan, jenis tegakan total lamun yang tertinggi ditemukan oleh jenis $H$. uninervis sebanyak 2.189 individu dari total keseluruhan transek $\left(24 \mathrm{~m}^{2}\right)$ kemudian diikuti oleh jenis $S$. isoetifolium dengan total 1.660 individu dari keseluruhan transek. Untuk kemunculan jenis lamun tertinggi pada masing-masing stasiun di Pantai Sanur ditemukan pada jenis E. acroides dan diikuti oleh $H$. uninervis. Kemunculan jenis lamun yang paling jarang yakni jenis $C$. serrulata. Kemunculan lamun tertinggi ini berkorelasi dengan yang dikemukakan oleh Arthana (2004) bahwa spesies yang umum dijumpai di Pantai Sanur adalah jenis $E$. acoroides dan jenis ini memiliki toleransi tertinggi untuk berkembang di Pantai Sanur dan lamun jenis $E$. acoroides ini memiliki daun yang lebih tebal, lebar dan panjang, sehingga memiliki ruang fotosintesa yang lebih besar per individunya.

Jenis $H$. uninervis merupakan kehadiran jenis pembuka dengan jumlah tegakan/ individu yang lebih banyak dibandingkan jenis $E$. acroides dan jenis lainnya. Namun berdasarkan nilai biomassa terhadap jenis lamun yang mendominasi, dimana jenis Enhalus acroides mempunyai nilai biomassa yang lebih tinggi dibandingkan dengan $H$. uninervis. Hal ini diakibatkan oleh faktor morfologi yakni jenis E. acroides lebih besar diantara jenis lamun yang ada di pantai Sanur. Semakin besar ukuran lamun, jumlah individu yang dapat mendiami suatu luasan tertentu akan berkurang (Fauziyah, 2004). Hal ini berkorelasi (sesuai) dengan penelitian ini yakni antara jenis yang paling sering ditemukan antara $H$. uninervis dengan $E$. acroides.

Jumlah jenis lamun yang telah ditemukan di Indonesia sebanyak 12 jenis lamun (Larkum et al, 1989). Sedangkan jenis lamun yang telah terinventarisasi di wilayah pesisir provinsi Bali berjumlah 10 jenis (Sudiarta dan Sudiarta, 2011). Di kawasan Pantai Sanur ditemukan $66 \%$ dari total jenis lamun yang ada di Indonesia dan $80 \%$ dari total jenis lamun yang ada di provinsi Bali. Sehingga tingkat keanekaragaman jenis lamun di kawasan pantai Sanur termasuk dalam kriteria tinggi.

\subsection{Stok Karbon Lamun}

Jenis lamun yang mempunyai nilai kandungan karbon tertinggi adalah $E$. acroides dilihat dari setiap transek yang ditemukan jenis $E$. acroides ini maka nilai biomassa dan kandungan karbonnya cenderung 
lebih besar dibandingkan transek lain yang ditemukan jenis lamun selain $E$. acroides. Sehingga jenis lamun ini mempunyai konstribusi terbesar sebagai penyimpan karbon di kawasan Pantai Sanur. Secara umum hasil penelitian ini menunjukkan bahwa rata-rata stok karbon lamun sebesar $20,68 \mathrm{gC} / \mathrm{m}^{2}$ dengan total stok penyimpanan karbon keseluruhan luas area sebesar 66,60 ton dengan luas area padang lamun di Pantai Sanur sebesar $322 \mathrm{Ha}$, dimana sekitar $60 \%$ disimpan sebagai stok karbon bagian bawah substrat dan 40 \% disimpan sebagai stok karbon bagian atas substrat. Menurut penelitian Supriadi (2012) yang dilakukan di Pulau Baranglompo Makassar menyebutkan bahwa total stok karbon lamun sebesar 73,86 ton dengan luas area sebesar 64,3 ha. Dari hasil tersebut terlihat bahwa stok karbon lamun di pantai Sanur lebih kecil dan dengan luasan lima kali jauh lebih besar daripada stok karbon lamun di pantai Baranglompo. Tingginya nilai stok karbon di Baranglompo dibandingkan dengan di Pantai Sanur dikarenakan pada penelitian di Baranglompo stok karbon lamun diperoleh tidak hanya dari tumbuhan lamun saja namun diperoleh dari produktivitas serasah dan herbivora (grazing bulu babi) sedangkan penelitian di Pantai Sanur stok karbon lamun hanya diperoleh dari tumbuhan lamun saja. Sudiarta dan Restu (2011) menyebutkan bahwa kondisi tutupan lamun di pantai Sanur termasuk kategori tutupan rendah (miskin) sampai moderat; menurut Kepmen LH No. 200 Tahun 2004 tentang Kriteria Baku Kerusakan dan Penentuan Status Padang Lamun. Sehingga kategori tutupan lamun yang rendah sampai moderat di Pantai Sanur ini berkorelasi dengan biomassa dan kandungan karbon yang terkandung pada tumbuhan lamun tersebut.

\subsection{Peran Lamun Sebagai Carbon Sink}

Kemampuan ekosistem lamun sebagai penyimpan karbon pada bagian tubuh lamun maupun yang tersimpan di dalam sedimen membuat ekosistem lamun berperan penting di wilayah pesisir. Kemampuan lamun mengendapkan bahan organik tersuspensi dengan kerapatan tunasnya menambah peran lamun sebagai penimbun karbon (Kennedy et al, 2004).

Luas lamun yang terinventarisasi di pesisir Bali sekitar 1.316 ha (Sudiarta dan Sudiarta, 2011). Jika diperkirakan rata-rata kondisi lamun di Bali relatif sama dengan kondisi lamun di Pantai Sanur, maka total stok karbon lamun di Bali diestimasi mencapai 272,15 ton. Selanjutnya Duarte et al. (2012) mengemukakan bahwa dengan luas yang kurang dari $0.1 \%$ dari permukaan laut, padang lamun dapat menimbun sekitar $20 \%$ dari total karbon yang tertimbun di laut. Namun saat ini kerusakan vegetasi pesisir khususnya ekosistem lamun relatif cepat. Kondisi padang lamun di seluruh lautan Indonesia sekitar 75-90\% rusak (Sumadhiharga, 2009).

Padang lamun di kawasan Pantai Sanur termasuk dalam kawasan pariwisata dan mengalami tekanan lingkungan seperti faktor alam dan terutama oleh aktivitas manusia yang mempengaruhi keberadaan lamun tersebut sehingga mempengaruhi kemampuannya dalam menyimpan karbon. Menurut Sudiarta dan Sudiarta (2011), kerusakan padang lamun di Pantai Sanur sebesar $15 \%$, tergolong pada tingkat kerusakan rendah. Dengan demikian diperlukan upaya pengelolaan ekosistem pesisir dan laut secara terpadu khususnya ekosistem lamun. Padang lamun di Pantai Sanur harus dapat mengimbangi antara fungsi ekologis dan biologisnya dengan lokasi Pantai Sanur sebagai peruntukkan kawasan wisata. Selain itu, pengelolaan ekosistem pesisir dan laut secara terpadu tersebut untuk mempertahankan keberadaan lamun agar konstribusi terhadap ekosistem di sekitarnya semakin besar serta mengoptimalkan peran lamun sebagai carbon sink sebagai upaya untuk perbaikan lingkungan.

\section{SIMPULAN DAN SARAN}

\subsection{Simpulan}

1. Ditemukan delapan jenis spesies lamun di kawasan Pantai Sanur yang tergolong dalam dua famili yaitu $H$. uninervis, $S$. isoetifolium, $H$. ovalis, H. pinifolia, E. acroides, C. rotundata, T. hemprichii dan C. Serrulata.

2. Rata-rata nilai kandungan karbon jaringan lamun pada akar sebesar 21,92 \% dari total berat kering (biomassa), daun sebesar 18,69 dan rizhoma sebesar $15,99 \%$.

3. Peran penting padang lamun sebagai penyimpan karbon terdiri dari konstribusi stok karbon di bawah substrat (akar dan rizhoma) sebesar 60 $\%$ atau 39,85 ton dan konstribusi stok karbon di atas substrat (daun) sebesar $40 \%$ atau 26,75 ton.

4. Total stok karbon padang lamun sebesar 66,60 ton dengan rata-rata 0,21 ton/ ha. Jenis yang berperan penting sebagai penyimpan karbon yakni $E$. acroides. Lamun jenis ini mempunyai nilai biomassa yang tinggi dan mempunyai ukuran morfologi yang besar serta terdistribusi dengan luas di kawasan Pantai Sanur.

\subsection{Saran}

1. Penelitian ini baru menghitung potensi penyerapan karbon lamun berdasarkan satu periode pengambilan (pengukuran) sampel, sehingga diperlukan penelitian lebih lanjut untuk mengukur produktivitas tumbuhan lamun untuk mengetahui fluktuasi yang terjadi antar periode (musim).

2. Perlu dilakukan penelitian lebih lanjut mengenai penyimpanan stok karbon melalui serasah lamun dan herbivora yang hidup di padang lamun untuk melengkapi peran lamun sebagai carbon sink. 


\section{DAFTAR PUSTAKA}

Aminudin. 2008. Kajian Potensi Cadangan Karbon Pada Pengusahaan Hutan Rakyat (Studi kasus: hutan rakyat Dengok, Kecamatan Playen, Kabupaten Gunung Kidul) (tesis). Bogor: Sekolah Pascasarjana, Institut Pertanian Bogor.

Arthana, I. W. 2004. Jenis Dan Kerapatan Padang Lamun Di Pantai Sanur Bali, Denpasar: Universitas Udayana.

Dinas Peternakan, Perikanan dan Kelautan Kota Denpasar. 2014. Survei Potensi Perikanan Budidaya dan Perikanan Tangkap Kota Denpasar. Denpasar.

C.M. Duarte., Fourqurean, J.W., H. Kennedy., N. Marba, M. Holmer., M.A. Mateo., E. Apostolaki., G.A. Kendrick., D. Krause-Jensen., K.J. McGlathery., and O. Serrano. 2012. Seagrass Ecosystems As a Globally Significant Carbon Stock. (article) Nature Geoscience. DOI: 10.1038/ NGEO1477.

Fauziyah, I. M. 2004. Struktur Komunitas Padang Lamun di Pantai Batu Jimbar Sanur (Skripsi). Bogor: Institut Pertanian Bogor.

Kawaroe, M. 2009. Perspektif Lamun Sebagai Blue Carbon Sink di Laut. (Lokakarya Lamun). Departemen Ilmu dan Teknologi Kelautan Fakultas Perikanan dan Ilmu Kelautan. Bogor: Institut Pertanian Bogor.
Keputusan Menteri Negara Lingkungan Hidup No. 200 Tahun 2004 tentang Kriteria Baru Kerusakan dan Pedoman Penentuan Status Padang Lamun.

Larkum, A.W.D., A.J.Mc. Comb and S. A. Shepherd. 1989. Biology of Seagrass: A Treatise On The Biology Of Seagrases With Special Reference To The Australian Religion in: Aquatic Plant Studies 2. Elsevier. Amsterdam.

Philips, C.R. and E.G. Menez. 1988. Seagrass. Smith Sonian Institutions. Press. Washington.

Sulaeman, Suparto dan Eviati. 2005. Petunjuk Teknis Analisis Tanah, Tanaman, Air dan Pupuk. Bogor: Balai Penelitian Tanah, Badan Penelitian dan Pengembangan Pertanian, Departemen Pertanian.

Supriadi. 2012. Stok dan Neraca Karbon Komunitas Lamun di Pulau Barranglompo Makassar (disertasi). Bogor: Institut Pertanian Bogor.

Sudiarta, I.K. dan I.G. Sudiarta. 2011. Status Kondisi dan Identifikasi Permasalahan Kerusakan Padang Lamun di Bali. Jurnal Mitra Bahari 5 (2): 103-126.

Sudiarta, I.K. dan Restu, I.W. 2011. Kondisi dan Strategis Pengelolaan Komunitas Lamun di Wilayah Pesisir Kota Denpasar, Provinsi Bali. Denpasar:. Jurnal Bumi Lestari 2 (2). 